University of Wollongong

Research Online

Faculty of Engineering and Information

Faculty of Engineering and Information

Sciences - Papers: Part A

Sciences

$1-1-2016$

\title{
Performance of high strength concrete columns reinforced with hybrid steel fiber under different loading conditions
}

\author{
Emdad K. Z Balanji \\ University of Wollongong, ekzb996@uowmail.edu.au \\ M Neaz Sheikh \\ University of Wollongong, msheikh@uow.edu.au \\ Muhammad N. S Hadi \\ University of Wollongong, mhadi@uow.edu.au
}

Follow this and additional works at: https://ro.uow.edu.au/eispapers

Part of the Engineering Commons, and the Science and Technology Studies Commons

\footnotetext{
Research Online is the open access institutional repository for the University of Wollongong. For further information
} contact the UOW Library: research-pubs@uow.edu.au 


\title{
Performance of high strength concrete columns reinforced with hybrid steel fiber under different loading conditions
}

\author{
Abstract \\ The strength and ductility of high strength concrete columns improve with the addition of steel fiber. This \\ paper reports the behavior of circular High Strength Concrete (HSC) columns reinforced with Hybrid Steel \\ Fibers (HSF) under different loading conditions. In this study, HSF consisted of a combination of macro \\ steel fibers and micro steel fibers. A total of eight circular specimens of $205 \mathrm{~mm}$ diameter and $800 \mathrm{~mm}$ \\ height were cast and tested. All specimens were reinforced with same amount of steel reinforcements. \\ The specimens were divided into two groups of four specimens. Group RC (reference group) contained no \\ steel fibers. Group HSF (hybrid steel fibers) contained $2.5 \%$ by volume of HSF. From each group one \\ specimen was tested under concentric loading, one under $25 \mathrm{~mm}$ eccentric loading, one under $50 \mathrm{~mm}$ \\ eccentric loading, and one under four-point loading. The results showed that the specimens reinforced \\ with HSF achieved higher strength and ductility compared to RC specimens under different loading \\ conditions. It was also observed that the presence of HSF delayed the spalling of the concrete cover.

\section{Disciplines} \\ Engineering | Science and Technology Studies

\section{Publication Details} \\ Balanji, E. K. Z., Sheikh, M. Neaz. \& Hadi, M. N. S. (2016). Performance of high strength concrete columns \\ reinforced with hybrid steel fiber under different loading conditions. In R. Komurlu, A. Gurgun, A. Singh \& \\ S. Yazdani (Eds.), Interaction Between Theory and Practice in Civil Engineering and Construction: \\ Proceedings of the First European and Mediterranean Structural Engineering and Construction \\ Conference (pp. 35-40). United States: ISEC Press.
}


The First European and Mediterranean Structural Engineering and Construction Conference EURO-MED-SEC-1,

Istanbul, Turkey, May 24-29, 2016,

Interaction between Theory and Practice in Civil Engineering and Construction

Edited by Komurlu, R., Gurgun, A., Yazdani, S., and Singh, A.

Copyright (c) 2016 ISEC Press

ISBN: 978-0-9960437-2-4

\title{
PERFORMANCE OF HIGH STRENGTH CONCRETE COLUMNS REINFORCED WITH HYBRID STEEL FIBRE UNDER DIFFERENT LOADING CONDITIONS
}

\author{
EMDAD K.Z. BALANJI, M. NEAZ SHEIKH and MUHAMMAD N.S. HADI \\ School of Civil, Mining and Environmental Engineering, University of Wollongong, \\ NSW, Australia
}

\begin{abstract}
The strength and ductility of high strength concrete columns improve with the addition of steel fiber. This paper reports the behavior of circular High Strength Concrete (HSC) columns reinforced with Hybrid Steel Fibers (HSF) under different loading conditions. In this study, HSF consisted of a combination of macro steel fibers and micro steel fibers. A total of eight circular specimens of $205 \mathrm{~mm}$ diameter and $800 \mathrm{~mm}$ height were cast and tested. All specimens were reinforced with same amount of steel reinforcements. The specimens were divided into two groups of four specimens. Group RC (reference group) contained no steel fibers. Group HSF (hybrid steel fibers) contained $2.5 \%$ by volume of HSF. From each group one specimen was tested under concentric loading, one under $25 \mathrm{~mm}$ eccentric loading, one under $50 \mathrm{~mm}$ eccentric loading, and one under four-point loading. The results showed that the specimens reinforced with HSF achieved higher strength and ductility compared to RC specimens under different loading conditions. It was also observed that the presence of HSF delayed the spalling of the concrete cover.
\end{abstract}

Keywords: Macro steel fibers, Micro steel fibers, Columns, Ductility, Eccentric loading, Concentric loading, Hybrid steel fibers.

\section{INTRODUCTION}

In structural applications, the use of High Strength Concrete (HSC) is on the rise due to its high compressive strength and high durability. One of the most common structural applications of HSC is in the columns of high rise buildings, where Normal Strength Concrete (NSC) results in larger cross sectional area and higher costs. However, lower ductility and brittle failure are obstacles for the application of HSC. The inclusion of fibers into HSC improves its structural performance, such as flexural strength, impact resistance, tensile strength, flexural toughness and ductility (Mohammadi et al. 2008). Adding a single type of fiber can improve the properties of Fiber Reinforced Concrete (FRC) to a limited level. However, the optimum improvement in mechanical properties of the FRC can be achieved by combinations of two or more different types of fiber namely as (hybrid fibers) in concrete (Chi et al. 2014). A number of researchers have studied the effect of a single type of fiber on concrete columns under concentric loads (Mangat and Azari 1985, Ganesan and Murthy 1990, Paultre et al. 2010, Palanivel and Sekar 2013, Balanji et al. 2015), under cyclic load (Lee 2007, Tokgoz 2009) and a few 
studies were conducted under eccentric load (Hadi 2008, Trapko 2014). Based on the existing research studies, it was found that the strength and ductility of the columns vary based on different parameters such as distribution and tensile strength of the longitudinal steel bars, configuration, spacing and tensile strength of the transverse reinforcements. For FRC columns, fiber type, volume content, aspect ratio and orientation of the fibers play an important role in enhancing the strength and ductility of the concrete columns. Using hybrid steel fibers with a combination of micro and macro fibers in HSC columns may further improve in the strength and ductility. Thus, the main objective of this study is to investigate the behavior of circular HSC columns reinforced with hybrid steel fibers under different loading conditions.

\section{EXPERIMENTAL PROGRAM}

\subsection{Test Specimens}

A total eight FRC specimens were cast and tested. The dimensions of the specimens were chosen to be $205 \mathrm{~mm}$ in diameter and $800 \mathrm{~mm}$ in height. According to the Australian Standards AS-3600 (2009), all specimens were reinforced with the same amount of longitudinal and spiral reinforcements. For longitudinal reinforcement, 6 deformed steel bars of $12 \mathrm{~mm}$ diameter (6N12) with $500 \mathrm{MPa}$ nominal tensile strength were used. For spiral reinforcement, plain steel bars of $10 \mathrm{~mm}$ diameter and $60 \mathrm{~mm}$ pitch (R10@60 mm) with $250 \mathrm{MPa}$ nominal tensile strength were used. The specimens cover was maintained on $20 \mathrm{~mm}$. The specimens were divided into two groups of four specimens. Group RC contained no steel fibers. Group HSF contained $2.5 \%$ by volume of HSF i.e., a combination of $1 \%$ by volume of macro steel fibers and $1.5 \%$ by volume of micro steel fibers.

In each group, one specimen was tested under an axial concentric load and designated as 0 . The second specimen was tested under an axial load with $25 \mathrm{~mm}$ eccentric load and designated as 25 . The third specimen was tested under an axial load with $50 \mathrm{~mm}$ eccentric load and designated as 50 . The fourth specimen was tested as a beam under four-point loading and designated as B. All specimens were tested at the laboratories of the School of Civil, Mining and Environmental Engineering, University of Wollongong, Australia.

\subsection{Material Properties}

High Strength Concrete (HSC) provided by a local supplier was used to form the specimens. The average compressive strength was $60 \mathrm{MPa}$ at 28-day. Two different steel fibers of deformed macro steel fibers $(18 \mathrm{~mm}$ length, $0.55 \mathrm{~mm}$ diameter and nominal tensile strength of $800 \mathrm{MPa})$ and straight micro steel fibers $(6 \mathrm{~mm}$ length, 0.2 $\mathrm{mm}$ diameter and nominal tensile strength of $2600 \mathrm{MPa}$ ) were used to reinforce the specimens.

\subsection{Casting and Curing Procedure}

In order to form the specimens, PVC formworks with an inner diameter of $205 \mathrm{~mm}$ and a length of $800 \mathrm{~mm}$ were used. HSC was placed directly from the concrete chute into the concrete mixer in order to include HSF into the concrete. The mix drum was filled to the required height so the total volume for each group of specimens was $0.12 \mathrm{~m}^{3}$. 
The mixer was switched on for 90 to 120 seconds until the fibers were uniformly mixed in the concrete. All the specimens were cured in the formwork for seven days by covering them with wet hessian and a plastic sheet to prevent moisture loss. After seven days the specimens were removed from the formwork and cured in the same moist condition for a further 21 days.

\section{TEST SETUP}

Prior to testing, the six specimens under axial compression were capped with a hard plaster to ensure uniform loading faces. Both ends of specimens were wrapped with 75 mm width Carbon Fiber Reinforced Polymer (CFRP) sheet in order to prevent premature failure. The eccentric load was applied through two special loading heads with the grooves at $25 \mathrm{~mm}$ and $50 \mathrm{~mm}$ off center. Two monitoring systems were used to measure the axial and lateral deformations of the specimens. For concentric loading, two Linear Variable Differential Transducers (LVDT) were fixed directly to the 5000 $\mathrm{kN}$ Denison Universal Testing Machine (UTM) to measure the axial deformation of the specimens during the test. For eccentric loading, in addition to the two LVDTs, a laser triangulation was installed at mid-height of the specimens to measure the lateral deformation of the specimens. Four-point loading was applied to the two beam specimens with clear span of $705 \mathrm{~mm}$ to investigate the bending capacity of the specimens with and without HSF. A laser triangulation was placed in the mid-span on the tension side of the specimen to determine the mid-span deflection. All specimens were tested under displacement control with a loading rate of $0.3-0.5 \mathrm{~mm} / \mathrm{min}$. Figure 1 shows a typical testing setup for the compression and four-point loading.

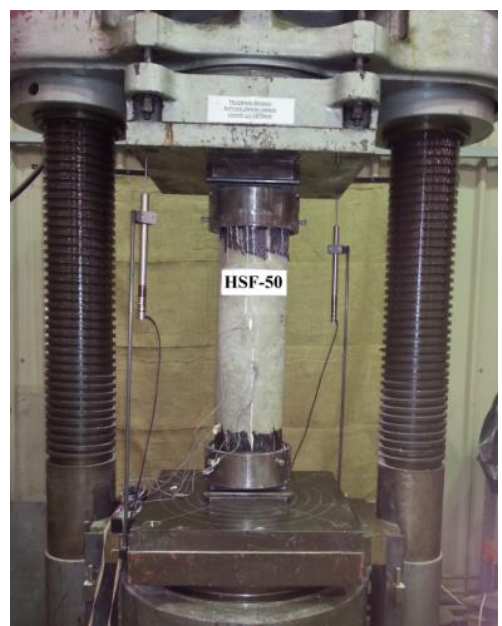

(a)

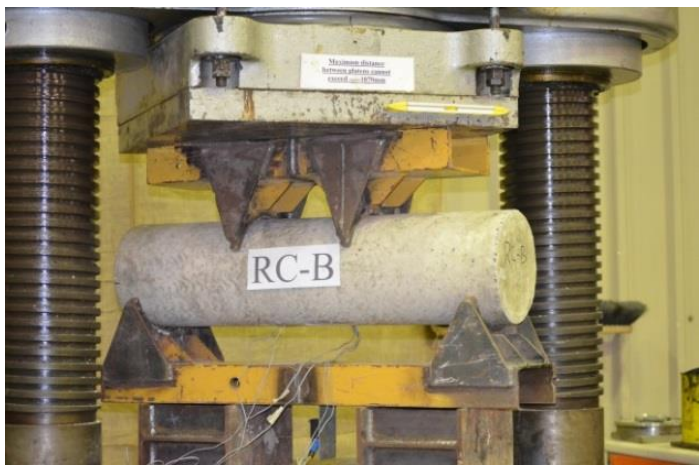

(b)

Figure 1. Test setup: (a) axial compression and (b) four-point loading.

\section{EXPERIMENTAL RESULTS AND DISCUSSION}

Results of all the specimens tested under different eccentric loading are presented in Table 1. Results of the beam specimens are presented in Table 2. Ductility is a parameter that used to investigate the performance of the specimens under different loading conditions (Hadi and Schmidt 2002, Sheikh and Legeron 2014). In this study, 
the ductility of the specimens was measured by using the deformation at $80 \%$ of the maximum load $\left(\Delta_{80}\right)$ in the descending part of the axial load and axial deformation curve divided by the deformation at yield load $\left(\Delta_{1}\right)$. The yield load was assumed to be the load corresponding to an approximation of the limit of the elastic behavior.

Table 1. Results of specimens under different eccentric loading.

\begin{tabular}{|c|c|c|c|c|c|c|c|}
\hline \hline \multirow{2}{*}{ Specimens } & \multicolumn{2}{|c|}{ Load (kN) } & \multicolumn{4}{c|}{ Deformation (mm) } & \multirow{2}{*}{ At maximum load } \\
\cline { 2 - 6 } & \multirow{2}{*}{ Yield } & \multirow{2}{*}{ Maximum } & \multicolumn{2}{c|}{ At yield load } & At muty \\
\cline { 4 - 7 } & & Axial & Lateral & Axial & Lateral & \\
\hline \hline RC-0 & 1681 & 1827 & 2.16 & - & 2.57 & - & 3.15 \\
\hline HSF-0 & 1990 & 2196 & 2.70 & - & 3.36 & - & 3.51 \\
\hline RC-25 & 1140 & 1140 & 2.37 & 1.48 & 2.37 & 1.48 & 1.65 \\
\hline HSF-25 & 1168 & 1270 & 2.16 & 1.01 & 2.65 & 1.62 & 2.52 \\
\hline RC-50 & 661 & 697 & 2.11 & 1.83 & 2.39 & 2.25 & 1.53 \\
\hline HSF-50 & 803 & 857 & 2.13 & 1.97 & 2.44 & 2.56 & 2.52 \\
\hline \hline
\end{tabular}

Table 2. Results of specimens under four-point loading.

\begin{tabular}{|c|c|c|c|c|c|}
\hline \hline \multirow{2}{*}{ Specimens } & \multicolumn{2}{|c|}{ Load (kN) } & \multicolumn{2}{c|}{ Mid-span deflection (mm) } & \multirow{2}{*}{ Ductility } \\
\cline { 2 - 5 } & Yield & Maximum & At yield & At maximum & \\
\hline \hline RC-B & 228 & 294 & 4.38 & 16.66 & 5.49 \\
\hline HSF-B & 302 & 398 & 5.48 & 30.84 & 6.47 \\
\hline \hline
\end{tabular}

\subsection{Specimens under Axial Loading and Four-Point Loading}

Figure 2 shows the load-deformation curves of the specimens under different loading conditions. Figure 2 (a) presents the axial load versus axial deformation of the specimens tested under concentric axial loading. The load of Specimen RC-0 suddenly dropped after spalling of the concrete cover, followed by buckling of the longitudinal steel bars and rupture of the spiral reinforcement. For Specimen HSF-0, the dilation in the lateral direction was observed without spalling of concrete cover due to the contribution of HSF. The maximum load of Specimen HSF-0 was 20\% higher than Specimen RC-0. The ductility of Specimen HSF-0 was increased by $11 \%$ compared with Specimen RC-0. This indicates that the addition of HSF into HSC makes the specimens more ductile due to the beneficial effects of macro and micro steel fibers. While micro steel fibers arrested the micro crack, macro steel fibers arrested wider cracks.

Figure 2 (b) and (c) present the axial load and deformation of the specimens in axial and lateral directions for specimens tested under $25 \mathrm{~mm}$ and $50 \mathrm{~mm}$ eccentric loading, respectively. Specimens RC-25 and RC-50 failed by sudden loss of the concrete cover at the maximum load and buckling of the longitudinal steel bars in the compression zone. No cover spalling was observed for Specimens HSF-25 and HSF-50, and the test was stopped after a loud noise. For all specimens under different eccentricities the formation and development of horizontal cracks in the tension face and vertical cracks in the compression face were observed. The maximum load for Specimen HSF-25 increased by $11 \%$ compared with Specimen RC-25. The inclusion of HSF led to improvement in ductility of the specimens. The ductility increased by $50 \%$ for 
Specimen HSF-25 compared with Specimens RC-25. For the specimens under $50 \mathrm{~mm}$ eccentricities, Specimen HSF-50 showed the largest increase in the maximum load compared with Specimen RC-50. Maximum load was increased by 23\% for Specimen HSF-50. The enhancement in ductility was about $60 \%$ for Specimen HSF-50 compared to Specimen RC-50.

Figure 2 (d) presents four-point loading and corresponding mid-span deflection for the specimens. It can be seen that the maximum load was significantly increased for Specimen HSF-B compared to Specimen RC-B. The maximum load of Specimen HSF$\mathrm{B}$ increased by $35 \%$ compared to Specimen RC-B. It was found that the ductility of the specimens improved by the inclusion of HSF. The ductility was increased approximately by $18 \%$ for Specimen HSF-B, compared to Specimen RC-B.

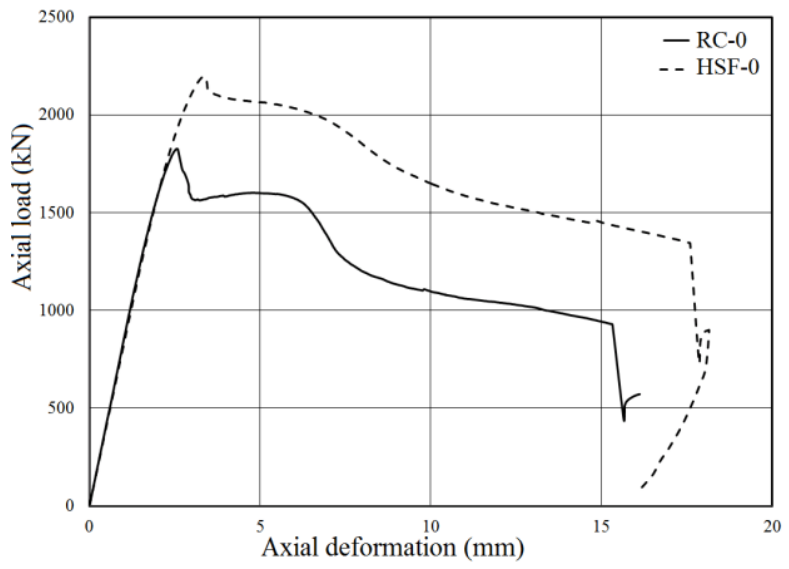

(a)

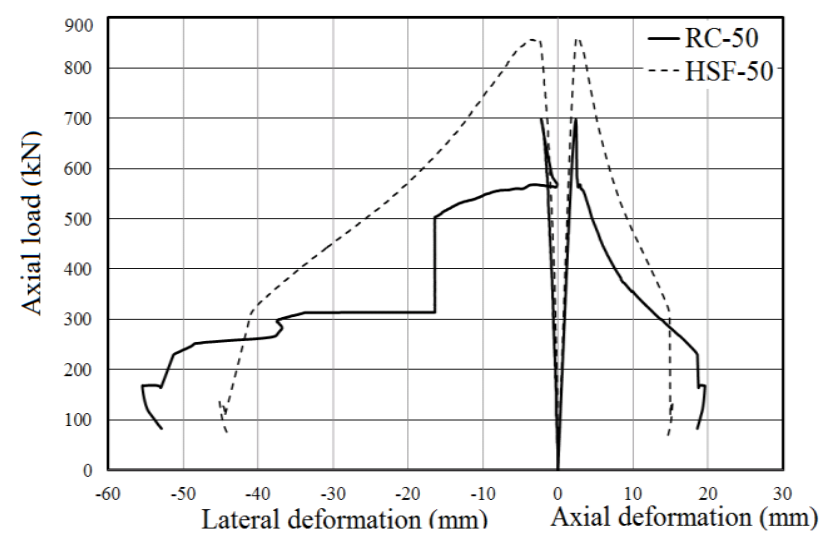

(c)

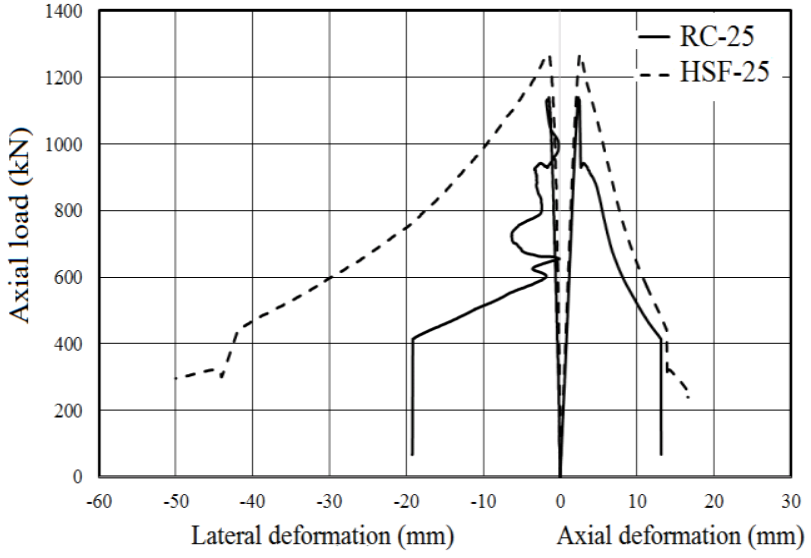

(b)

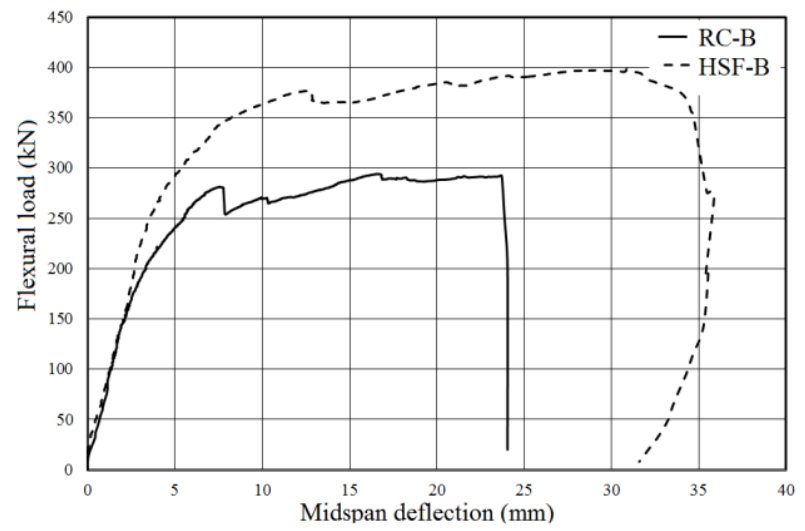

(d)

Figure 2. Test results for the specimens under (a) concentric compression (b) $25 \mathrm{~mm}$ eccentric compression (c) 50 mm eccentric compression and (d) four-point loading.

\section{CONCLUSIONS}

The behavior of circular HSC specimens with and without Hybrid Steel Fibers (HSF) was experimentally investigated. Six specimens were tested as columns under concentric, $25 \mathrm{~mm}$ and $50 \mathrm{~mm}$ eccentric loadings and two specimens were tested as 
beams under four-point loading. The experimental results showed that the maximum load of Specimens HSF were considerably higher than Specimens RC. Specimens HSF exhibited higher ductility than Specimens RC. The enhancements in the strength and ductility of the Specimens reinforced with HSF are due to the functions of macro and micro steel fibers.

\section{REFERENCES}

AS 1391, Metallic Materials-Tensile Testing at Ambient Temperature, Australian Standard 1391:2007.

AS 3600, Concrete Structures, Australian Standard 3600:2009.

Balanji, E., Sheikh, M. N. \& Hadi M. N.S., Models For Predicting The Axial Compressive Strength of Steel Fiber Reinforced Normal and High Strength Concrete Square Columns, in the 12th International Symposium on Fiber Reinforced Polymers for Reinforced Concrete Structures \& The 5th Asia-Pacific Conference on Fiber Reinforced Polymers in Structures Joint Conference, Nanjing, China, 14-16 December 2015.

Chi, Y., Xu, L. \& Zhang, Y., Experimental Study on Hybrid Fiber-Reinforced Concrete Subjected to Uniaxial Compression, Journal of Materials in Civil Engineering, 26(2), 211-218, 2014.

Ganesan, N. \& Murthy, J. V., Strength and Behavior of Confined Steel Fiber Reinforced Concrete Columns, ACI Materials Journal, 87(3), 221-227, 1990.

Hadi, M. N. \& Schmidt, L. C. X, Use of Helixes in Reinforced Concrete Beams", ACI Structural Journal, 99(2), 2002.

Hadi, M. N. S, Behavior of Fiber RC Columns Wrapped with FRP Under Eccentric Loads, Australasian Structural Engineering Conference (ASEC), Melbourne, Australia, 26 - 27 June 2008.

Lee, H. H., Shear Strength and Behavior of Steel Fiber Reinforced Concrete Columns Under Seismic Loading, Engineering Structures, 29(7), 1253-1262, 2007.

Mangat, P. S. \& Azari, M., Influence of Steel Fiber and Stirrup Reinforcement on the Properties of Concrete in Compression Members, International Journal of Cement Composites and Lightweight Concrete, 7(3), 183-192, 1985.

Mohammadi Y., Singh P. \& Asushik S.K., Properties of Steel Fibrinous Concrete Containing Mixed Fibers in Fresh and Hardened State, Construct and Build Material, 22, 956-65, 2008.

Palanivel, S. \& Sekar, M., Constitutive Behavior of Lateral Ties Confined Polyolefin Fiber Reinforced Concrete Under Monotonic Axial Compression, Applied Mechanics and Materials, 253-255, 2013.

Paultre, P., Eid, R., Langlois, Y. \& Ĺvesque, Y., Behavior of Steel Fiber-Reinforced HighStrength Concrete Columns Under Uniaxial Compression, Journal of Structural Engineering, 136(10), 1225-1235, 2010.

Sheikh, M. N. \& Légeron, F., Performance Based Seismic Assessment of Bridges Designed According to Canadian Highway Bridge Design Code, Canadian Journal of Civil Engineering, 41(9), 777-787, 2014.

Tokgoz, S., Effects of Steel Fiber Addition on the Behavior of Biaxial Loaded High Strength Concrete Columns, Materials and Structures, 42(8), 1125-1138, 2009.

Trapko, T., Behavior of Fiber Reinforced Cementitious Matrix Strengthened Concrete Columns Under Eccentric Compression Loading, Materials \& Design, 54, 947-954, 2014. 